\title{
AGE RELATED DIFFERENCES AND EVALUATION OF THE BALL SPEED OF IN-STEP KICK IN FOOTBALL
}

\author{
Marin Gadev \& Petar Peev \\ National Sports Academy “Vassil Levski”, Sofia, Bulgaria
}

\begin{abstract}
Authors research the influence of different factors onto the ball speed of in-step kick in football. The purpose of our research is to add and expand the knowledge of this problem as we follow the age-related trend of change in the ball speed (power of the shot) of in-step kick in football. First of all, this will help us to define the most appropriate period for developing the power of the shot and also, we can quantify this development. The results of Independent sample t-test define the periods of 15-16 years and 19+ years as the most appropriate in this direction. On the basis of the results we propose norms for evaluation of the shot power in every age group. This is additional premise for optimization and control of the training process in youth soccer.
\end{abstract}

Key words: football, in-step kick, ball speed, norms, evaluation

\section{INTRODUCTION}

Main topic in research about the ball speed of instep kick in football are connected with the anatomic characteristics of the players, technique of execution and biomechanics in different age groups (Gadev, et al. 2001; Dörge, et al. 2002; Young, et al. 2004; Markovic, et al. 2006; Rodríguez-Lorenzo, et al. 2015; Bekris, et al. 2015; García-Pinillos, et al. 2015; Takahashi et al. 2016).

Other researchers study the relationship of ball speed with the anthropometric indicators and the power of the shot (Manolopoulos et al., 2004; Apriantono et al., 2006; Cerrah, et al. 2011; Young and Rath, 2011; Noguchi, et al. 2012; Brahim, et al. 2013; Rodríguez-Lorenzo, et al., 2016; Gadev, Peev, 2019). All sides of this problem help to expand our knowledge about the problem of the ball speed of in-step kick in football. We surely must point out that the main factor of the ball speed is the technique of execution which can be accomplished only when we have appropriate level of fitness (Koloskov, 1981; Bachvarov, 1992; Korenberg, 2005; Seluyanov et al. 2012; Marinova, 2016). It is well known fact that good fitness level contributes in unique way for better execution of the in-step kick in football. In this line of thoughts, the evaluation of the ball speed of in-step kick, can helps us from one side to assess the fitness level and from the other the technique of the shot.

\section{Aims and objectives}

Shooting is the main way of scoring goals in football. In this regard it will be interesting and import- ant to consider this problem as one of the major actions in football. Until now we didn't find any similar research in the literature in Bulgaria and abroad. All of the mentioned above leads us to the main purpose of the research. It is to optimize the control of training process and selection of young football players. That's why we set as an objective to create age related normative for evaluation of the ball speed of the in-step kick.

\section{METHODS}

Main method that we used to solve the task of the research is ball speed measurement. The ball speed of the shot was measured with radar speed gun "Speedchek" (SCX-01, Tribar Industries Inc., Ontario, Canada) with the following characteristics: Speed detection display range - $\max 199 \mathrm{~km} / \mathrm{h}$; Distance range - approx. $10 \mathrm{~m}$; Accuracy $\pm 2-3$ $\mathrm{km} / \mathrm{h}$; Signal size $-60^{\circ}$ vertical by $40^{\circ}$ horizontal.

The device was 10 meters away from the ball to avoid registration of the swinging motion of the leg. The shot was made in front of a net without goalkeeper with the main purpose of maximal effort in the kicking. Every player made 3 attempts as we registered the best of them. The players do the test one by one in exact order with enough time for fully recovery. Before the test all the players made a standard warm up. The age-related differences were measured in for different age groups. These groups were defined by Stoyanov (2005) and they are as followed: kids (12-14 years) in total 26 football players; junior men (15-16 years) - 24 players; senior men (17-18 years) - 24 players; men (19+) 
- 22 players. The entire sample was 96 football players.

The statistical procedures were made with SPSS Statistics 19 (IBM, Chicago, Illinois, USA). We used descriptive statistics and Independent sample t-test. The main indicators that we used were average $(\mathrm{X})$, standard deviation $(\mathrm{S})$, standard error of mean (SE), range (R), minimal and maximal results $\left(\mathrm{x}_{\text {min }} ; \mathrm{x}_{\text {max }}\right.$, asymmetry (As), kurtosis (Ex) and coefficient of variation $(\mathrm{CV})$.

\section{RESULTS}

The results from age related differences of the ball speed of in-step kick in football and their descriptive statistics of them are summarized in Table 1.

Table 1. Age related differences of the ball speed of in-step kick in football

\begin{tabular}{|c|c|c|c|c|}
\hline \multirow{2}{*}{$\begin{array}{c}\text { Statistical } \\
\text { Indicators } \Omega\end{array}$} & \multicolumn{4}{|c|}{ Age groups $\sqrt{ }$} \\
\hline & $12-14$ years & 15 - 16 years & $17-18$ years & $\begin{array}{c}19+ \\
\text { years }\end{array}$ \\
\hline $\mathbf{X}$ & 73,8 & 91,5 & 96 & 104,25 \\
\hline SE & 3,07 & 2,29 & 1,41 & 1,98 \\
\hline $\mathbf{S}$ & 9,20 & 5,90 & 4,84 & 5,62 \\
\hline Es & $-0,82$ & $-0,71$ & 0,02 & $-0,14$ \\
\hline As & $-0,42$ & 0,78 & $-0,19$ & 0,97 \\
\hline $\mathbf{R}$ & 28 & 18 & 14 & 15 \\
\hline $\mathbf{x}_{\min }$ & 58 & 84 & 89 & 99 \\
\hline $\mathbf{x}_{\max }$ & 86 & 102 & 103 & 114 \\
\hline$V \%$ & 12,47 & 7,08 & 4,41 & 5,39 \\
\hline
\end{tabular}

The results of ball speed of in-step kick in football, that are shown in table 1 , are homogenous for all the researched groups (V\% - 4,41-12,47). The greatest value is in the first group (12-14 years) which in our opinion is a consequence of a lower level of muscle coordination and the different technique of execution. In proof of this is the $\mathrm{R}$ coefficient which is greatest in this age group.

Results are evidence for an increase of ball speed of in-step kick in football over time of growing. The age-related differences are in the range $\left(\mathrm{x}_{\min } и \mathrm{x}_{\max }\right)$ of 58 to $114 \mathrm{~km} / \mathrm{h}$ for the whole sample.

Our results are normally distributed for all of the researched age groups, so this allows us to use Independent sample t-test (As and Ex are lower than the $\mathrm{As}_{0,05}$ and $\mathrm{Ex}_{0,05}$ values). In order to define the statistical significance of the results of the different age groups of the tested indicator we did a Student T-test (Table 2). All of the differences in table 3 are significant $\left(t_{\text {emp }}\right.$ $<\mathrm{t}_{\alpha}$ in level of agreement $\left.\alpha=0,05\right)$.

Table 2. Statistical significance of the differences of ball speed of in-step kick in football

\begin{tabular}{|c|c|c|c|c|c|c|c|c|c|}
\hline \multirow{2}{*}{ № } & \multicolumn{2}{|c|}{ Age groups $\Omega$} & \multicolumn{7}{|c|}{ Statistical indicator $\sqrt{ }$} \\
\cline { 3 - 10 } & \multicolumn{2}{|c|}{} & $\mathbf{x}_{1}$ & $\mathbf{x}_{2}$ & $\mathbf{d}$ & $\mathbf{d} \%$ & temp & $\mathbf{t}_{\sigma}$ & $\mathbf{k}$ \\
\hline 1. & $12 / 14$ years & $15 / 16$ years & 73,8 & 91,5 & 17,7 & 24,0 & 6,58 & 2,01 & 48 \\
\hline 2. & $15 / 16$ years & $17 / 18$ years & 91,5 & 96 & 4,5 & 4,9 & 2,73 & 2,01 & 46 \\
\hline 3. & $17 / 18$ years & $19+$ years & 96 & 104,25 & 8,25 & 8,6 & 3,47 & 2,01 & 44 \\
\hline
\end{tabular}

\section{DISCUSSION}

Greatest increase of the ball speed of in-step kick in football is at age of group 15-16 years $(17,7$ $\mathrm{km} / \mathrm{h}$ ). In our opinion this increase of the results is due to the great anthropometric changes after puberty (age 14). They are mainly related with increased height and weight, which lead up to an increase of the muscle mass. In the end all these changes in concordance of increased relative power potential contribute for greater ball speed of this shot in football.

The next peak increase of the ball speed of in-step kick in football is in the last group (19+ years $\mathrm{d}=$ $8,25 \mathrm{~km} / \mathrm{h}$ ). This peak in our opinion is conse- 
quence of an improvement of the neuromuscular coordination of the lower limbs. Undeniable result of this is the improvement of the player's coordination which leads to a greater precision of the efforts in time and space. Consequently, of all this - greater technique of execution of the kick.
On the basis of descriptive statistics (normal distribution of the variables) and the significant differences of the results we compounded norm tables for the research indicator. They are based on Martin's method of the three-sigma rule (68-95-99,7 rule) for normally distributed data (table 3 ).

Table 3. Age related normative table of the ball speed of in-step kick in football

\begin{tabular}{|c|c|c|c|c|}
\hline \multirow[b]{2}{*}{ Rating Љ } & \multicolumn{4}{|c|}{ Age groups } \\
\hline & $\begin{array}{l}12-14 \\
\text { years }\end{array}$ & $\begin{array}{l}15-16 \\
\text { years }\end{array}$ & $\begin{array}{c}17-18 \\
\text { years }\end{array}$ & $\begin{array}{c}19+ \\
\text { years }\end{array}$ \\
\hline Excellent & Over 92 & Over 103 & Over 106 & Over 115 \\
\hline Very Good & $83-91$ & $97-103$ & $101-106$ & $110-114$ \\
\hline Good & $65-82$ & $86-97$ & $91-100$ & 99-109 \\
\hline Average/Sufficient & $55-64$ & $80-85$ & $86-91$ & $93-98$ \\
\hline Weak /Insufficient & Under 54 & Under 80 & Under 86 & Under 93 \\
\hline
\end{tabular}

As a conclusion we can mark that there are two favorable periods of development of the ball speed of in-step kick in football: first period 15-16 years and second period $19+$ years. In addition of the conclusion and in taking into account some of the psychophysiological characteristics we can propose the following:

- Thefirst periodismorefavorable for development of the neuromuscular coordination;

- In the second period coaches should emphasize on the work of the strength and explosive power of the lower limbs in relation of the work for neuromuscular coordination.

The proposed normative table is a predisposition for optimization of this side of the performance of the young football players.

\section{REFERENCES}

Apriantono, T., Nunome, H., Ikegami, Y. and Sano, S. (2006). The effect of muscle fatigue on instep kicking kinetics and kinematics in association football, Journal of sports sciences, 24(9), pp. 951-960;

Bachvarov, M. (1992). Konditsionnata podgotovka na futbolista, Sofia, NSA - IPB/ Бъчваров, M. (1992) Кондиционната подготовка на футболиста, София, НСА - ИПБ/;

Bekris, E., Gioldasis, A., Bekris, V., Gissis, I., Komsis, S. and Mitrousis, I. (2015). The relationship of kicking bal. velocity with anthropometric and physiological factors in soccer, Sport Science Review, 24(1-2), pp. 71-87;

Cerrah, A. O., Gungor, E. O., Soylu, A. R., Ertan, H., Lees, A. and Bayrak, C. (2011). Muscular activation pat- terns during the soccer in-step kick, Isokinetics and Exercise Science, 19(3), pp. 181-190;

Dörge, H. C., Andersen, T. B., SØrensen, H. and Simonsen, E. B. (2002). Biomechanical differences in soccer kicking with the preferred and the non-preferred leg. Journal of sports sciences, 20(4), 293-299;

Gadev, M., Tishinov, O., Mardov, I. (2001). Vzaimovrazka na skorostta na topkata s nyakoy biomehanichni parametri pri izpalnenie na prav udar ot niskokvalifitsirani futbolisti, Sport i nauka, 3, pp. 9-15 // Гъдев, М., Тишинов, О., Мардов, И. (2001). Взаимовръзка на скоростта на топката с някой биомеханични параметри при изпълнение на прав удар от нискоквалифицирани футболисти, Спорт и наука, 3, ст. 9-15

Gadev, M., Peev, P. (2019). Correlation between power potential, anthropometry and the speed of the ball of instep kick in football (in press).

García-Pinillos, F., Ruiz-Ariza, A., Moreno del Castillo, R. and Latorre-Román, P. Á. (2015). Impact of limited hamstring flexibility on vertical jump, kicking speed, sprint, and agility in young football players, Journal of sports sciences, 33(12), pp. 1293-1297;

Koloskov, V., (1981) Neotlozhnыe zadachi, V kn. Futbol, (Ezhegodnik) Москжа., Fizkultuira i Sport, pp.45/ Колосков, В., (1981) Неотложные задачи, В кн. Футбол, (Ежегодник) М., ФuС, с.4-5 /

Korenberg, V., (2005) Osnovы sportivnoy kineziologii, Moskva, Sovetskiy sport, pp. 232/ Коренберг, В., (2005) Основы спортивной кинезиологии, Москва, Советский спорт, с. 232/;

Manolopoulos, E., Papadopoulos, C., Salonikidis, K., Katartzi, E. and Poluha, S. (2004). Strength training effects on physical conditioning and instep kick kine- 
matics in young amateur soccer players during preseason, Perceptual and motor skills, 99(2), pp. 701-710;

Marinova, T. (2016), izsledvane izmenenieto na skorostno-silovite vazmozhnosti pri visoko kvalifitsirana sastezatelka $\mathrm{v}$ distsiplinata troen skok, Leka atletika nauka, 1(16), st 105-112 // Маринова, Т. (2016), Изследване изменението на скоростно-силовите възможности при високо квалифицирана състезателка в дисциплината троен скок, Лека атлетика и наука, 1(16), ст. 105-112/;

Markovic, G., Dizdar, D. and Jaric, S. (2006). Evaluation of tests of maximum kicking performance, Journal of sports medicine and physical fitness, 46(2), pp. 215-220;

Masuda, K., Kikuhara, N., Takahashi, H. and Yamanaka, K. (2003). The relationship between muscle cross-sectional area and strength in various isokinetic movements among soccer players, Journal of sports sciences, 21(10), pp. 851-858;

Noguchi, T., Demura, S. I. and Nagasawa, Y. (2012). Relationship between ball kick velocity and leg strength: A comparison between soccer players and other athletes, Advances in Physical Education, 2(03), pp. 95-98;

Peev, P., Ivanova, G. (2015). Retrospektiven analiz na osnovni komponenti ot morfo-funktsionalno razvitie na podrastvashti futbolisti, Leka atletika $i$ nauka, st. 1(15), 66-72 // Пеев, П., Иванова, Г. (2015) Ретроспективен анализ на основни компоненти от морфо-функционално развитие на подрастващи футболисти, Лека атлетика и наука, 1(15), ст. 66-72 // Peev, P., Ivanova, G. (2015). Retrospektiven analiz na osnovni komponenti ot morfo-funktsionalno razvitie na podrastvashti futbolisti, Leka atletika i nauka, st. 1(15), 66-72/;

Rodríguez-Lorenzo, L., Fernandez-del-Olmo, M. and Martín-Acero, R. (2015). A critical review of the technique parameters and sample features of maximal kicking velocity in soccer, Strength \& Conditioning Journal, 37(5), pp. 26-39;

Rodríguez-Lorenzo, L., Fernandez-del-Olmo, M. and Martín-Acero, R. (2016). Strength and Kicking Perfor- mance in Soccer: A Review, Strength and Conditioning Journal, 38(3), pp. 106-116;

Rodríguez-Lorenzo, L., Olmo, F. D., Sánchez-Molina, J. A. and Martín-Acero, R. (2018). Kicking ability and kicking deficit in young elite soccer players, Kinesiology: International journal of fundamental and applied kinesiology, 50(2), pp. 80-82;

Seluyanov, V., K. Sarsania, V. Zaborova (2012) Futbol: problemы fizicheskoy i tehnicheskoy podgotovki, Dolgoprudnыy, INTELLEKTiK, pp.160 // Селуянов, B., К. Сарсания, В. Заборова (2012) Футбол: проблемы физической и технической подготовки, ДолгопрудныЙ, ИНТЕЛЛЕКТИК, с.160/;

Stoyanov, S., (2005) Uchebna programa po futbol za detsa i yunoshi, SOFIA, NSA PRES, pp.160 // Стоянов, C., (2005) Учебна програма по футбол за деца и юноши, София, НСА ПРЕС, с.210/;

Takahashi, S., Kawamoto, R., Kato, S., Saho, Y., Hirose, N. and Fukubayashi, T. (2016). Hip kinematics and muscle activity during inside soccer kick in players with a history of groin pain, In ISBS-Conference Proceedings Archive, November, 34, (1), pp. 371-374;

Young, W. B. and Rath, D. A. (2011). Enhancing foot velocity in football kicking: the role of strength training, The Journal of Strength \& Conditioning Research, 25(2), pp. 561-566;

Young, W., Clothier, P., Otago, L., Bruce, L. and Liddell, D. (2004). Acute effects of static stretching on hip flexor and quadriceps flexibility, range of motion and foot speed in kicking a football, Journal of Science and Medicine in Sport, 7(1), pp. 23-31.

\section{Corresponding author:}

Marin Gadev

Track and Field Department National Sports Academy "Vassil Levski", Sofia, Bulgaria, E-mail: margadev@hotmail.com 